\title{
Sequestering of iron and lead from groundwater using chemically modified Cucumis melo rind
}

\author{
Norzila Othman*, Syazwani Mohd Asharuddin \\ Faculty of Civil and Environmental Engineering, UTHM, 86400, Parit Raja, Johor, Malaysia. \\ * Corresponding author: norzila@uthm.edu.my
}

\section{Article history}

Received 31 January 2019

Revised 14 May 2019

Accepted 25 October 2019

Published Online 2 February 2020

\section{Graphical abstract}

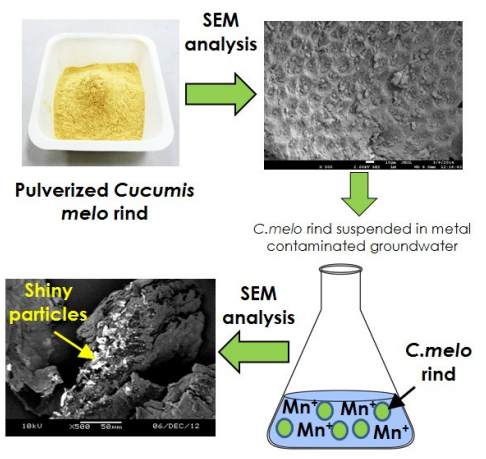

\begin{abstract}
Heavy metal contamination in groundwater is among the significant environmental issues which require high priority of remediation action due to its importance in our daily life. This study intended to upcycle Cucumis melo (C. melo) rind which a waste from agricultural industries as natural adsorbent to remove iron $(\mathrm{Fe})$ and lead $(\mathrm{Pb})$ ions from groundwater. The efficiency of $C$. melo rind to remove $\mathrm{Fe}$ and $\mathrm{Pb}$ under pre-determined optimum conditions were analyzed and the result showed that metal removal was up to $96.83 \%$ for $\mathrm{Fe}$ and $94.88 \%$ for $\mathrm{Pb}$ ions under $\mathrm{Fe}$ ion-optimized working conditions. While under $\mathrm{Pb}$ ion-optimized working conditions, the removal percentage obtained were up to $87.19 \%$ for $\mathrm{Fe}$ and $95.09 \%$ for $\mathrm{Pb}$ ion. Adsorption isotherm analysis data of both metal ions were fitted well to the Langmuir model with maximum adsorption capacity of $5.35 \mathrm{mg} / \mathrm{g}$ and 0.08 $\mathrm{mg} / \mathrm{g}$ for $\mathrm{Fe}$ and $\mathrm{Pb}$ ions respectively. The kinetics experimental data correlated well with the pseudosecond order kinetics model. From the characterization study of the biosorbent using scanning electron microscopy coupled with energy dispersive X-ray spectrometry (SEM-EDX), X-ray fluorescent spectrophotometry (XRF) and Fourier transform infrared spectrometry (FTIR), ion exchange and micro precipitation were estimated to be the main mechanism governing the biosorption process by $C$. melo rind. The results demonstrated that $C$. melo rind has the potential to be developed as the adsorbent material for the removal of $\mathrm{Fe}$ and $\mathrm{Pb}$ ions from groundwater.
\end{abstract}

Keywords: Biosorption, biosorbent, cucumis melo, groundwater, $\mathrm{Fe}$ ion, $\mathrm{Pb}$ ion

(C) 2020 Penerbit UTM Press. All rights reserved

\section{INTRODUCTION}

Metals such as iron and lead that are seeping into the environment naturally through rock and soils can cause adverse effect to human, flora, and fauna. The existence of the metals in groundwater beyond a certain level will turn the groundwater unfeasible for consumable. The metals polluted water may cause discoloration of food and beverages, metallic taste, odor, turbidity, staining of laundry, and plumbing fixtures (Mohamad Roslan et al., 2007; El-Araby et al., 2009; Abdul Aziz et al., 2017). Lengthen exposure to high concentration of metal contaminants may specifically cause organ system dysfunction that result in deficiency of growth and reproduction as well as neurological disorders (Hamilton et al., 2000).

Extensive number of researches has been done in exploring and improvising technologies for metals removal in polluted groundwater including chemical precipitation, coagulation, flocculation, membrane separation, reverse osmosis, and oxidation. Most of the methods demonstrate major shortcomings such as toxic sludge generation, chemical handling and disposal problems, high maintenance cost, technical constraints, and incomplete metal removal (Valdman et al., 2000; Hashim et al., 2011). Hence, in considering techno-economic constraints, the biosorption method was employed in this study to remove metal toxicants in groundwater.

Successful metal biosorption has been reported by numerous researches using variety of low-cost agricultural waste ranging from fruit seeds, husks, copra, leaves, and fibres (Othman et al., 2013; Othman et al., 2014). Though, to the best of our knowledge there is no literature that describes the feasibility of pre-treated Cucumis melo $(C$. melo) rind for heavy metals removal in groundwater. $C$. melo belongs to the family of Cucurbitaceae, is a tropical fruit that is best planted on soil temperature between $25{ }^{\circ} \mathrm{C}$ to $32{ }^{\circ} \mathrm{C}$. In Malaysia, melons including $C$. melo are mostly planted in Johor, Kedah, Kelantan, Terengganu, and Pahang. The cultivation of these crops covers almost $7.1 \%$ from the total agro food land in Malaysia which equivalent to 13, 814 hectares (Rasmuna et al., 2016). The rind is a non-profitable part of the fruit, which is a by-product of fruit juice industries and fruit stalls. Therefore, it is totally inexpensive and abundantly available.

The principal compounds present in the $C$. melo rind, pectin and $\alpha$-cellulose provide the function of rigidity and resistance to tearing of this fruit (Mohd-Asharuddin et al., 2017). These polymers are rich in functional groups such as hydroxyl and carboxyl which are known to strongly bind to metal cations in aqueous solution (Mohd-Asharuddin et al., 2019).

The detailed batch optimization studies have been published (Othman et al., 2013). In the present work, the pre-determined working conditions as obtained in the previous work were employed to determine the removal percentage of $\mathrm{Fe}$ and $\mathrm{Pb}$ ions from groundwater samples using $C$. melo rind. Isotherm and kinetics studies were also conducted, and the experimental data was fitted to isotherm and kinetics model to obtain in-depth understanding on the adsorption process. 


\section{EXPERIMENTAL}

\section{Biosorbent materials}

C. melo rind used in this study was obtained from various fruit stalls around Parit Raja, Batu Pahat, Johor. After the rind was thoroughly cleaned using distilled water to remove unwanted impurities, it was soaked in $15 \%$ Nitric Acid. The rind was washed again in distilled water to remove the acid residue followed by ovendrying at $60{ }^{\circ} \mathrm{C}$ until it reached constant weight before ground into powder of $<150 \mu \mathrm{m}$ particle size using laboratory ball mill (Zayadi et al., 2013).

\section{Preparation of metal solutions}

Stock solution $(1000 \mathrm{mg} / \mathrm{L})$ of $\mathrm{Fe}$ and $\mathrm{Pb}$ ion solutions were prepared by dissolving the appropriate amount of $\mathrm{FeCl}_{3} \cdot 6 \mathrm{H}_{2} \mathrm{O}$ and $\mathrm{Pb}$ $\left(\mathrm{NO}_{3}\right)_{2}$ in $100 \mathrm{~mL}$ pure water. Varied concentrations of metallic ion solutions ( 2.0 to $2.5 \mathrm{mg} / \mathrm{L}$ for Fe ion; 0.01 to $0.05 \mathrm{mg} / \mathrm{L}$ for $\mathrm{Pb}$ ion) were prepared by diluting the stock solution. The $\mathrm{pH}$ adjustment of the solutions was made using $0.1 \mathrm{M}$ Glacial Acetic Acid and $0.1 \mathrm{M}$ $\mathrm{NaOH}$, utilizing a $\mathrm{pH}$ hand-held $\mathrm{pH}$ meter (Hach). Synthetic metal ion solutions were prepared for kinetics and isotherm studies.

\section{Groundwater sampling}

Samples of groundwater were collected from groundwater tube well located at Research Centre for Soft Soil, RECESS, UTHM in Parit Raja, Batu Pahat, Johor. The sampling process was done according to APHA (1998). The concentration of the heavy metals in the groundwater was analyzed using Perkin-Elmer Atomic Adsorption Spectrometer (AAS).

\section{Sorption studies using actual groundwater samples}

The working conditions applied to the present experiment as tabulated in Table 1 were obtained from the optimum working conditions based on the previous study on the removal of $\mathrm{Fe}$ and $\mathrm{Pb}$ ions using $C$. melo rind in synthetic aqueous solutions (Othman et al., 2013). The sorption experiments were carried out by using suspension of $0.05 \mathrm{~g}$ of C. melo rind in $100 \mathrm{~mL}$ of metallic solutions of various concentrations in $250 \mathrm{~mL}$ Erlenmeyer flasks. The suspensions were shaken on an orbital shaker at $125 \mathrm{rpm}$ for 45 minutes at room temperature of $25{ }^{\circ} \mathrm{C}$. The $\mathrm{pH}$ of the groundwater samples were adjusted to 6.5 and 7.0. The biosorbent was separated from the groundwater solution by glass filtration set. Residual metal concentration in the filtrate was determined using AAS analysis while the biosorbent residue was analyzed using SEM-EDX and FTIR. All experiments were performed in triplicates.

\section{Kinetics studies}

Kinetics study were carried out in batch at optimum conditions as listed in Table 1 and varied contact times $(1,3,5,10,15,20,30,45$, $60,120,150,180,210,240,270,300 \mathrm{~min})$. The samples were immediately filtered after each time intervals and the residual metal concentration in the filtrate was analyzed using AAS. The data collected were modeled using Pseudo-first order and Pseudo-second order kinetics models.

\section{Isotherm studies}

The adsorption isotherm study was performed using predetermined optimum conditions with a series of $\mathrm{Fe}$ and $\mathrm{Pb}$ ion solutions containing different metal ion concentrations for each ion (in the range of $2.0-2.5 \mathrm{mg} / \mathrm{L}$ for Fe ion solutions; $0.01-0.05 \mathrm{mg} / \mathrm{L}$ for $\mathrm{Pb}$ ion solutions). All suspensions were filtered and metal residues in the filtrates were analyzed using AAS. The data collected were modeled using Langmuir, Freundlich, and BET isotherm models.

\section{Biosorbent characterization using SEM-EDX, XRF, and FTIR analysis}

Native and metal-loaded biosorbents were subjected to SEM-EDX microscopy (JEOL) for surface morphological and elemental analyses. Elemental compositions of the biosorbent were analyzed using XRF (Perkin Elmer) while chemical functional groups present on native and metal-loaded $C$. melo rind were characterized using FTIR (Perkin Elmer).

\section{Data analysis of biosorption efficiency}

The metal bound per gram of biomass was determined using the mass balance. The percentage of metal removal and uptake capacity of $\mathrm{Fe}$ and $\mathrm{Pb}$ were determined using Eq. (1) and (2):

$$
\text { Sorption }(\%)=[(C 0-C f) / C 0] \times 100
$$

where $\mathrm{C} 0$ is the initial metal concentration $(\mathrm{mg} / \mathrm{L})$ and $\mathrm{Cf}$ is the final metal concentration $(\mathrm{mg} / \mathrm{L})$.

$$
q=(C O-C f)(V / m)
$$

where $\mathrm{q}$ is the metal uptake $(\mathrm{mg} / \mathrm{g}), \mathrm{C} 0$ is the initial metal concentrations in solution $(\mathrm{mg} / \mathrm{L}), \mathrm{Cf}$ is the final metal concentrations in solution $(\mathrm{mg} / \mathrm{L}), \mathrm{V}$ is the volume of solution $(\mathrm{L})$, and $\mathrm{m}$ is the mass of biosorbent $(\mathrm{g})$.

\section{RESULTS AND DISCUSSION}

\section{Sorption studies using actual groundwater}

The adsorption study using groundwater samples were performed by employing the pre-determined optimum working conditions for both $\mathrm{Fe}$ and $\mathrm{Pb}$ ions as listed in Table 1 to evaluate the effect of different working conditions on metal selectivity of $C$. melo rind due to the fact of groundwater contains multi-ion compositions. The minimum and maximum $\mathrm{Fe}$ and $\mathrm{Pb}$ ions concentration in the groundwater samples are presented in Table 2. The metals concentrations generally exceed the acceptable level by World Health Organization (WHO, 2004) and Malaysia National Guidelines for Raw Drinking Water Quality (Benchmark for Groundwater) (MOH, 2000). Similar observation was demonstrated by Azimah et al. (2012) on a study of metal contents in groundwater of RECESS monitoring well in 2012 where $\mathrm{Fe}$ and $\mathrm{Pb}$ ionic concentrations were found to be the highest in the groundwater.

\begin{tabular}{|c|c|c|c|c|c|c|}
\hline \multirow[b]{2}{*}{ Metal ions } & \multicolumn{4}{|c|}{ Optimum value } & \multirow[b]{2}{*}{$\begin{array}{l}\text { Percentage } \\
\text { Removal (\%) }\end{array}$} & \multirow{2}{*}{$\begin{array}{c}\text { Optimum } \\
\text { Uptake } \\
\text { Capacity } \\
\text { (mg/g) }\end{array}$} \\
\hline & $\mathrm{pH}$ & $\begin{array}{c}\text { Contact } \\
\text { time } \\
\text { (minute) }\end{array}$ & $\begin{array}{c}\text { Initial Metal Ion } \\
\text { Concentration } \\
(\mathrm{mg} / \mathrm{L})\end{array}$ & $\begin{array}{l}\text { Biosorbent } \\
\text { Dosage }(g)\end{array}$ & & \\
\hline $\mathrm{Fe}$ & 7.0 & 45 & 2.0 & 0.05 & 99.60 & 4.98 \\
\hline $\mathrm{Pb}$ & 6.5 & 45 & 0.03 & 0.05 & 94.44 & 0.05 \\
\hline
\end{tabular}

Table 1 Percentage of removal and uptake capacity of all parameters at optimum working conditions (Othman et al., 2013). 
This observation is in agreement with the result reported by Nurazim et al. (2015) on a study of metal contents in pumping well near Sungai Kerian, Perak where the contents of $\mathrm{Fe}^{2+}(6.220 \mathrm{mg} / \mathrm{L})$ violated the $\mathrm{WHO}$ limit.

Table $2 \mathrm{Fe}$ and $\mathrm{Pb}$ concentration of RECESS groundwater samples.

\begin{tabular}{lcc}
\hline Sample & $\begin{array}{c}\text { Fe } \\
\text { Concentration } \\
\text { (mg/L) }\end{array}$ & $\begin{array}{c}\text { Pb } \\
\text { Concentration } \\
\text { (mg/L) }\end{array}$ \\
\hline $\begin{array}{l}\text { Minimum Metal } \\
\text { Concentration }\end{array}$ & 2.119 & 0.073 \\
\hline $\begin{array}{l}\text { Maximum Metal } \\
\text { Concentration }\end{array}$ & 3.734 & 0.237 \\
\hline Mean & 2.967 & 0.161 \\
\hline WHO limits & 2.000 & 0.010 \\
\hline $\begin{array}{l}\text { NGRDWQ for } \\
\text { (benchmark } \\
\text { groundwater) }\end{array}$ & 0.300 & 0.010 \\
\hline
\end{tabular}

After sorption study was done under Fe ion-optimized conditions ( $\mathrm{pH}$ : 7, biosorbent dosage: $0.05 \mathrm{~g}$, contact time: 45 minutes), the average removal percentage of $\mathrm{Fe}$ and $\mathrm{Pb}$ ions were $90.73 \%$ and $88.36 \%$, respectively. In another sorption study using $\mathrm{Pb}$ ionoptimized conditions ( $\mathrm{pH}$ : 6.5, biosorbent dosage: $0.05 \mathrm{~g}$, contact time: 45 minutes), the respective average removal percentage were $90.94 \%$ and $82.44 \%$ for $\mathrm{Pb}$ and $\mathrm{Fe}$ ions. Such removals have successfully reduced the concentration of $\mathrm{Fe}(0.50 \mathrm{mg} / \mathrm{L})$ and $\mathrm{Pb}(0.01$ $\mathrm{mg} / \mathrm{L}$ ) ions to achieve the standards recommended by WHO.

The metal selectivity in the removal of metal by $C$. melo rind can be arranged in the order of $\mathrm{Fe}>\mathrm{Pb}$ based on the average metal uptakes. Such trend could be explained in terms of the difference in the ionic sizes of the metal ions, the rate and distribution of active groups on the sorbent, and the mode of interaction between metal ions and the sorbent (A-Jacques et al., 2007). The ionic radius (Pauling) for $\mathrm{Fe}$ ion is $0.78 \AA$ while for $\mathrm{Pb}$ ion is $1.33 \AA$. It is suggested that the smaller the ionic diameter, the higher adsorption rate (Gerola et al., 2013).

Moreover, the presence of other competing ions may affect the metal uptake due to competition for the sorption sites on the surface of adsorbent. When the adsorption is particle diffusion controlled, it means that intraparticle mass transfer resistance is rate limiting (Yesim et al., 2000; Igwe et al., 2007). The competition between ionic species affects the diffusion properties of the metal ions, hence decreases the adsorption capacity of the metal ions. Thus, the metal ion that successfully reaches the adsorption site faster depends on the above factors including the ionic radii of the metal ions.

An interference study was performed using Delonix regia (Forest pods) on metal uptake with the presence of competing ions. The results indicated reduction in the biomass uptake of lead and nickel with the presence of competing ions of calcium, sodium and magnesium (Festus et al., 2013). Chatterjee and Schiewer (2014) study on the effect of competing cations of $\mathrm{Pb}$ and $\mathrm{Cd}$ in biosorption using citrus peels revealed that metal uptake was lower for bimetal systems than for mono-metal systems. The biosorbent showed higher affinity towards $\mathrm{Pb}$ than $\mathrm{Cd}$ that could be due to the surface adsorption on constituent group on substrates which plays a more vital contribution to adsorption capacity than the micro porous adsorption (Igwe et al., 2007).

\section{Metal sorption kinetics}

The results of the kinetics parameters for both $\mathrm{Fe}$ and $\mathrm{Pb}$ ions calculated from the linear plots of pseudo-first order and pseudosecond order kinetics models are presented in Table 3. The theoretical $\mathrm{q}_{\mathrm{eq}}$ values calculated from the pseudo-first order kinetics models for sorption of both metal ions gave significantly different values than that of $q_{\exp }$ values, and the $\mathrm{R}^{2}$ values for both metal ions were also found to be lower. The $\mathrm{R}^{2}$ is regarded as a measure of the goodnessof-fit of experimental data on the kinetics model (Ho, 2004). These results indicate that the biosorption of $\mathrm{Fe}$ and $\mathrm{Pb}$ ions by $C$. melo rind do not follow the first-order kinetic model.

The linear plots of $t / q t$ against $t$ for second-order equation result in straight lines for both metal ions (Fig. 1 and 2). The $\mathrm{R}^{2}$ values for both metal ions were also close to $1(0.99)$. The qeq values for both metal ions tested were also very close to the qexp values. All these results imply that the biosorption of $\mathrm{Fe}$ and $\mathrm{Pb}$ ions by $C$. melo rind followed the pseudo-second order kinetic model which assumes that biosorption may be the rate-limiting step involving valence forces through sharing or exchange of electrons between biosorbent and sorbate (Khamidun et al., 2014).

\section{Metal sorption isotherm}

The data from the isotherm studies were perfectly fitted to Langmuir isotherm which yielded regression coefficient $\left(\mathrm{R}^{2}\right)$ value near to 1 for both metal ( 0.99 for $\mathrm{Fe}$ and 0.98 for $\mathrm{Pb}$ ions) as presented in Fig. 3 and 4. The applicability of the Langmuir isotherm for the experimental data provides an initial indication that the governing mechanism is chemisorption with high possibility of monolayer adsorption of the metal ions which are occurring on the surface of the C. melo rind. Langmuir isotherm assumes that adsorption occurs at specific sites within the adsorbent (Langmuir, 1916). Therefore, once the metal ion occupying a site no further adsorption will take place at that site (Volesky et al., 1995).

The isotherms parameters are listed in Table 4. The sorption capacity, qmax which is a measure of maximum sorption capacity corresponding to complete monolayer coverage showed that the maximum metal uptake for $\mathrm{Fe}$ and $\mathrm{Pb}$ ions were $5.35 \mathrm{mg} / \mathrm{g}$ and 0.08 $\mathrm{mg} / \mathrm{g}$ respectively. The data conclude that the affinity of metal ions to bind to $C$. melo rind in the aqueous solutions was following the order of $\mathrm{Fe}>\mathrm{Pb}$.

Another essential characteristic of the Langmuir isotherm parameters can be used to predict the affinity between the sorbate and sorbent is using separation factor of dimensionless equilibrium parameter, $\mathrm{R}_{\mathrm{L}}$, which is expressed by the Eq. 3:

$$
R_{L}=\frac{1}{1+b C_{0}}
$$

where $b$ is the Langmuir constant and $C_{o}$ is the highest initial concentration of metal ions $(\mathrm{mg} / \mathrm{L})$.

The value of $R_{L}$ provides the important indication whether the isotherm is either unfavourable $\left(\mathrm{R}_{\mathrm{L}}>1\right)$, linear $\left(\mathrm{R}_{\mathrm{L}}=1\right)$, favourable $(0>$ $\mathrm{R}_{\mathrm{L}}>1$ ) or irreversible $\left(\mathrm{R}_{\mathrm{L}}=0\right)$ (Zeng et al., 2009). Sorption of both $\mathrm{Fe}$ and $\mathrm{Pb}$ ions by $C$. melo rind yields the $\mathrm{RL}$ values within the range of $0-1$ which indicating favorable biosorption process.

Table 3 Kinetics parameters of biosorption of $\mathrm{Fe}$ and $\mathrm{Pb}$ by $\mathrm{C}$. melo rind.

\begin{tabular}{|c|c|c|c|c|c|c|c|}
\hline \multirow{2}{*}{$\begin{array}{l}\text { Metal } \\
\text { ions }\end{array}$} & \multirow{2}{*}{$\begin{array}{c}q_{e}(\exp .) \\
(\mathrm{mg} / \mathrm{g})\end{array}$} & \multicolumn{3}{|c|}{ Pseudo-first order } & \multicolumn{3}{|c|}{ Pseudo-second order } \\
\hline & & $\begin{array}{l}q_{\mathrm{e}} \text { (cal.) } \\
\text { (mg/g) }\end{array}$ & $k_{1}\left(\min ^{-1}\right)$ & $\mathbf{R}^{2}$ & $\begin{array}{l}q_{\mathrm{e}} \text { (cal.) } \\
(\mathrm{mg} / \mathrm{g})\end{array}$ & $k_{2}\left(\min ^{-1}\right)$ & $\mathbf{R}^{2}$ \\
\hline $\mathrm{Fe}$ & 1.4800 & 1.1649 & 0.0002 & 0.1844 & 1.4120 & 1.5476 & 0.9987 \\
\hline $\mathrm{Pb}$ & 0.0550 & 0.8584 & -0.0029 & 0.3837 & 0.0564 & 3.9472 & 0.9997 \\
\hline
\end{tabular}




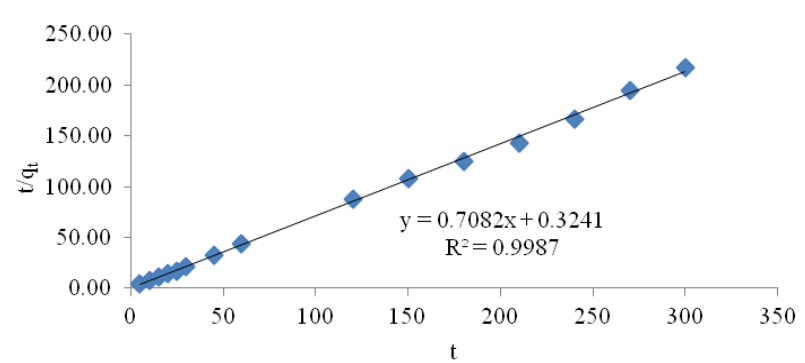

Fig. 1 Pseudo second-order kinetic model plot of Fe uptake by C. melo rind.

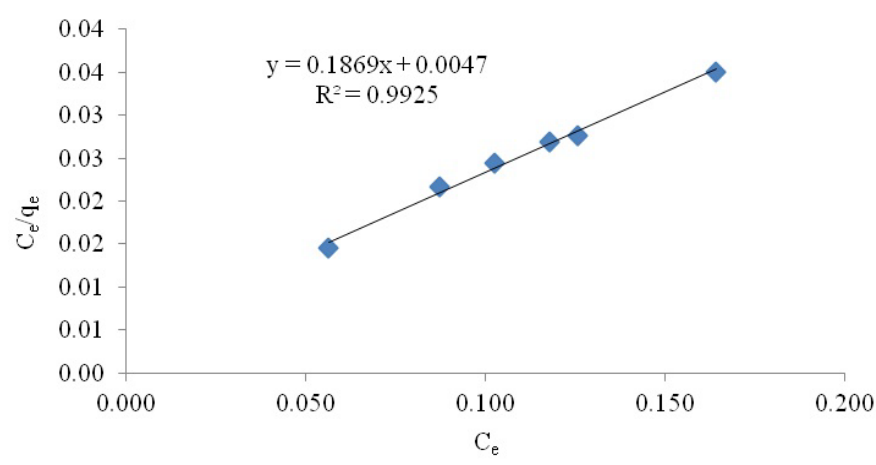

Fig. 3 Langmuir isotherm plot of Fe ion uptake by C. melo rind.

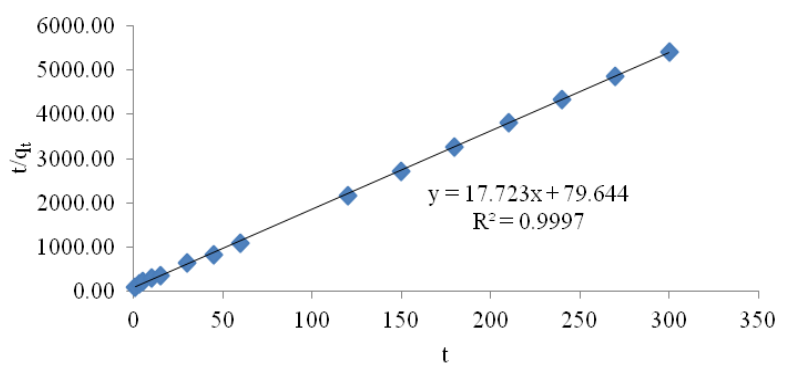

Fig. 2 Pseudo second-order kinetic model plot of Pb uptake by C. melo rind.

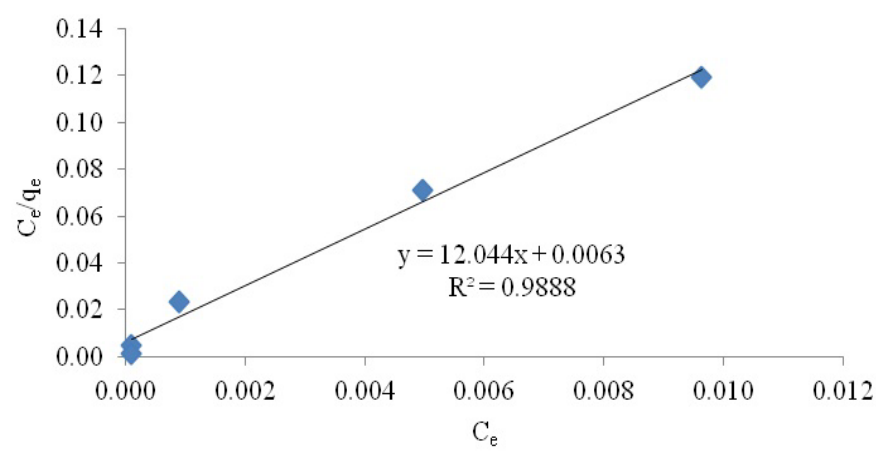

Fig. 4 Langmuir isotherm plot of $\mathrm{Pb}$ ion uptake by $\mathrm{C}$. melo rind.

Table 4 Isotherms parameters of biosorption of $\mathrm{Fe}$ and $\mathrm{Pb}$ ions onto C. melo rind.

\begin{tabular}{cccccccccc}
\hline \multirow{2}{*}{ Metal ion } & \multicolumn{3}{c}{ Langmuir } & \multicolumn{3}{c}{ Freundlich } & \multicolumn{3}{c}{ BET } \\
\cline { 2 - 11 } & $\begin{array}{c}\mathbf{q}_{\max } \\
\mathbf{m g} / \mathbf{g})\end{array}$ & $\begin{array}{c}\mathbf{b} \\
(\mathbf{L} / \mathbf{m g})\end{array}$ & $\mathbf{R}^{2}$ & $\mathbf{K}_{\mathbf{F}}$ & $\mathbf{n}$ & $\mathbf{R}^{2}$ & $\begin{array}{c}\mathbf{q}_{\mathbf{m}} \\
(\mathbf{m g} / \mathbf{g})\end{array}$ & $\mathbf{K}_{\mathbf{B}}$ & $\mathbf{R}^{2}$ \\
\hline $\mathrm{Fe}$ & 5.35 & 39.76 & 0.99 & 6.52 & 5.37 & 0.92 & 2.09 & -26.71 & 0.97 \\
\hline $\mathrm{Pb}$ & 0.08 & 1912.41 & 0.99 & 0.18 & 5.44 & 0.47 & 0.07 & 46.72 & 0.97 \\
\hline
\end{tabular}

\section{SEM-EDX analysis}

The surface of native $C$. melo rind was observed to be porous and rough as seen in Fig. 5. This shows a sign of good candidate for potential biosorbent. Larger and deepened pores were observed in acid-treated biosorbent (Fig. 6) which proven that the advantage of acid pretreatment in improving the quality of biosorbent by enlarging pores and consequently increasing the surface area for metal attachment (Noor-Syuhadah et al., 2012).

SEM micrographs of metal-loaded biosorbent were observed to be smoother than that of porous native biosorbent. There were shiny particles observed over the surface of biosorbent after the biosorption study was conducted. This observation evidenced the surface coverage of biosorbent by metal ions. The EDX analysis performed on the untreated biosorbent identified the presence of prominent $\mathrm{C}$ and $\mathrm{O}$ peaks and did not show the characteristics signal of $\mathrm{Fe}$ and $\mathrm{Pb}$. The analysis conducted on the shiny spots revealed new peaks between 0.00 to $3.00 \mathrm{keV}$ corresponding to $\mathrm{Fe}$ and $\mathrm{Pb}$ ions confirming the uptake of metals by the biosorbent.

\section{XRF analysis}

The chemical composition of C. melo rind is presented in Table 5. From the XRF analysis, it was also noted that the contents of several compound such as $\mathrm{SiO}_{2}, \mathrm{SO}_{3}$, and $\mathrm{Al}_{2} \mathrm{O}_{3}$ in acid-treated biosorbent were increased compared to untreated biosorbent. This could be due to pore enlargement which adding more surface area to the sorbent material which therefore contributing higher exposure of those elements content on the surface of the sorbent (Gerola et al., 2013).
$\mathrm{SiO}_{2}$ was found to be the most abundant component in the biosorbent. This finding is in parallel with the observation reported in a study of metal biosorption using rice husk. The major constituents of rice husk which may be responsible for sorption are carbon and silica (NoorSyuhadah et al., 2012). While in other study done by Azizul-Rahman (2014) on the adsorption of $\mathrm{Zn}$ by watermelon rind revealed that silica content was significantly reduced from $75.20 \%$ to $9.88 \%$ which reflects the involvement of silica in metal sorption. This finding could be due to the leaching of Si from the surface of the adsorbent material during the process of biosorption via redox reaction which forms metal oxides or due to substitution of metal ions at $\mathrm{Si}-\mathrm{OH}$ bonds. Besides, Rao et al. (2010) suggested that when the substituted metal ions has a lower charge, the net negative charge at the site enables adsorption of cations thus the presence of Si-OH bonds would also act as cation exchange centers.

\section{FTIR analysis}

The pattern of metal sorption onto the sorbent material is attributable to the functional groups present of the surface of the sorbent material. Fig. 9 shows the FTIR spectra of $C$. melo rind before and after the biosorption study. The band shifts demonstrated in the FTIR spectra of metal-loaded biosorbent confirmed changes in functional group and surface properties of the biosorbent. These shifts may be attributed to the changes in counter ions associated with hydroxyl, carboxyl groups which are predominant contributors in the complexation of metal ions and ion exchange processes (Iqbal et al., 2010; Mohd-Asharuddin et al., 2017). C. melo rind is principally 
made up of lignin and cellulose which bear functional groups such as alcohol, ketone, and carboxyl. These groups can be involved in complexation reaction with $\mathrm{Fe}$ and $\mathrm{Pb}$ ions.

The changes observed in the band between $3500-3200 \mathrm{~cm}^{-1}$ may be assigned to complexation of metal ions with the ionized $\mathrm{O}-\mathrm{H}$ groups of free hydroxyl groups and bonded $\mathrm{O}-\mathrm{H}$ group in polymeric compounds such as alcohols, phenols and carboxylic acids presented in pectin, cellulose and lignin on $C$. melo rind. The changes in the band between $3000-2850 \mathrm{~cm}^{-1}$ may indicate the mechanism of ion exchange that took place between protons of symmetric or

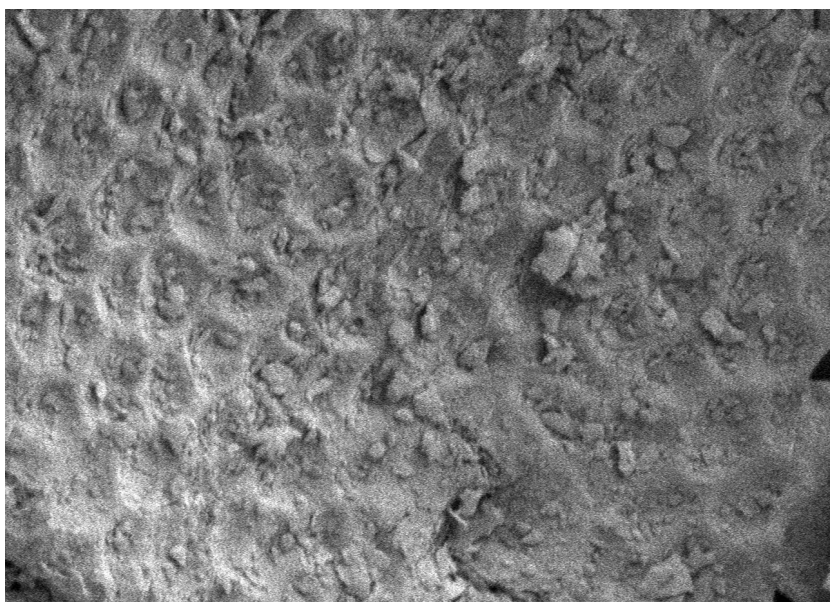

Fig. 5 SEM micrograph of native C. melo rind $(\times 500)$.
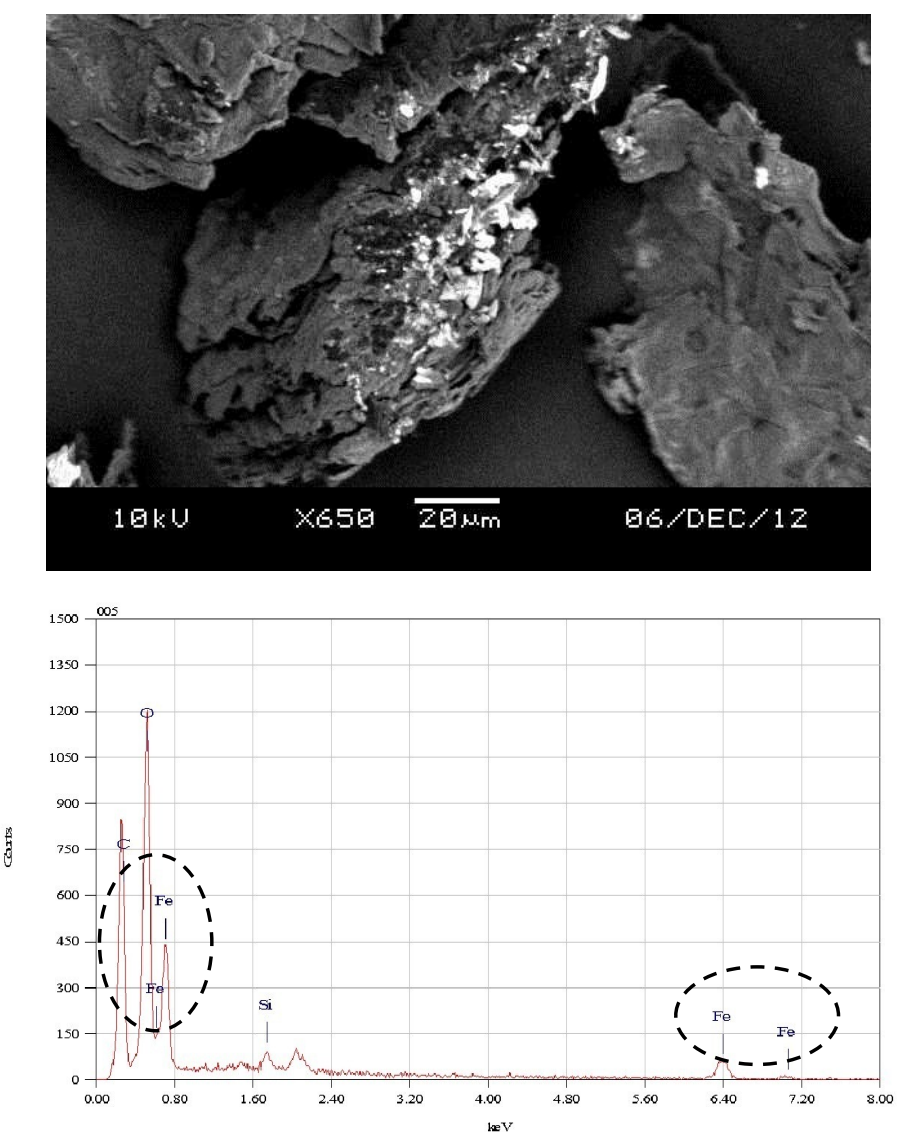

Fig. 7 SEM-EDX micrograph of C. melo rind after Fe sorption study $(\times 500)$. asymmetric $\mathrm{CH}$ and $\mathrm{CH}_{2}$ of aliphatic acids (Iqbal et al., 2009). While the peak between $1750-1680 \mathrm{~cm}^{-1}$ may be assigned to the stretching vibration of $\mathrm{C}=\mathrm{O}$ of carboxyl groups. The peak between $1640-1500$ $\mathrm{cm}^{-1}$ is may be due to the stretching vibration of ionic carboxylic groups $\left(-\mathrm{COO}^{-}\right)$of cellulose, which also may be indicative of electrostatic forces of attraction between negative charge of carboxylate anion and positive charge of $\mathrm{Fe}$ and $\mathrm{Pb}$ ions (Gerola et al., 2013). These observations are consistent with the study performed by Kamaruudzaman et al. (2013) where $-\mathrm{OH}$ and $-\mathrm{C}=\mathrm{O}$ functional groups were reported to be involved in the biosorption of $\mathrm{Pb}$ ions.

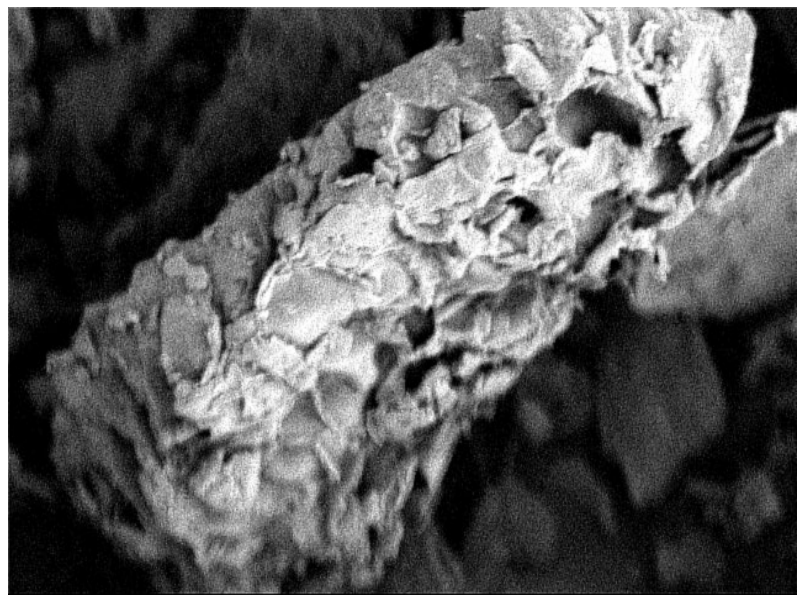

Fig. 6 SEM micrograph of acid-modified C. melo rind $(\times 500)$.
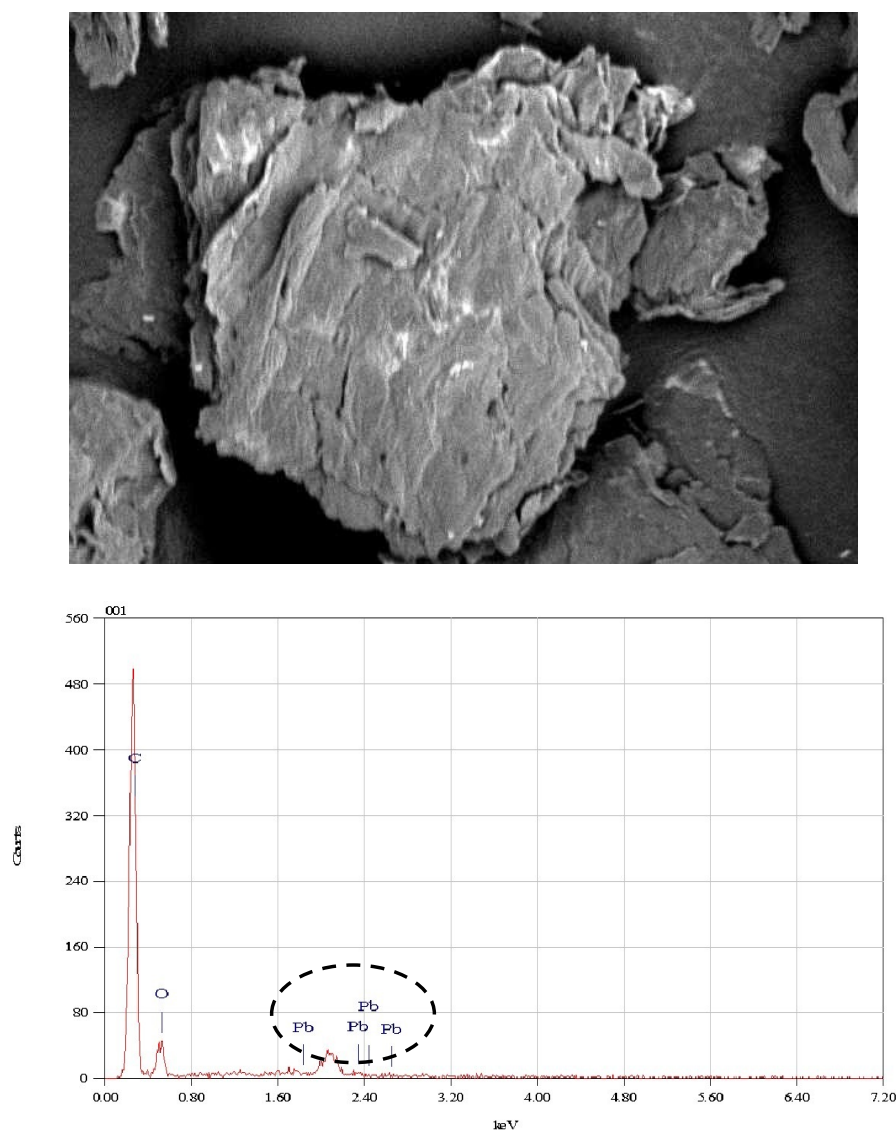

Fig. 8 SEM-EDX micrograph of $C$. melo rind after $\mathrm{Pb}$ sorption study $(\times 500)$ 
Table 5 The elemental composition of the C. melo rind.

\begin{tabular}{ccc}
\hline Formula & \multicolumn{2}{c}{ Constitution (\%) } \\
\hline & $\begin{array}{c}\text { Native } \\
\text { biosorbent }\end{array}$ & $\begin{array}{c}\text { Acid-treated } \\
\text { biosorbent }\end{array}$ \\
$\mathrm{CO}_{2}$ & $0.10 \%$ & $0.10 \%$ \\
$\mathrm{SiO}_{2}$ & $38.81 \%$ & $41.23 \%$ \\
$\mathrm{~K}_{2} \mathrm{O}$ & $18.90 \%$ & $16.00 \%$ \\
$\mathrm{SO}_{3}$ & $5.39 \%$ & $15.50 \%$ \\
$\mathrm{CaO}$ & $14.00 \%$ & $11.10 \%$ \\
$\mathrm{P}_{2} \mathrm{O}_{5}$ & $10.40 \%$ & $6.90 \%$ \\
$\mathrm{Al}_{2} \mathrm{O}_{3}$ & $1.27 \%$ & $4.28 \%$ \\
$\mathrm{Cl}$ & $3.25 \%$ & $1.59 \%$ \\
$\mathrm{TiO}_{2}$ & $1.25 \%$ & $1.00 \%$ \\
$\mathrm{MgO}_{\mathrm{CuO}}$ & $2.39 \%$ & $0.88 \%$ \\
$\mathrm{CnO}_{2}$ & $1.01 \%$ & $0.83 \%$ \\
$\mathrm{Fe}_{2} \mathrm{O}_{3}$ & $1.23 \%$ & $0.59 \%$ \\
$\mathrm{Mn}$ & $1.93 \%$ & - \\
\hline
\end{tabular}

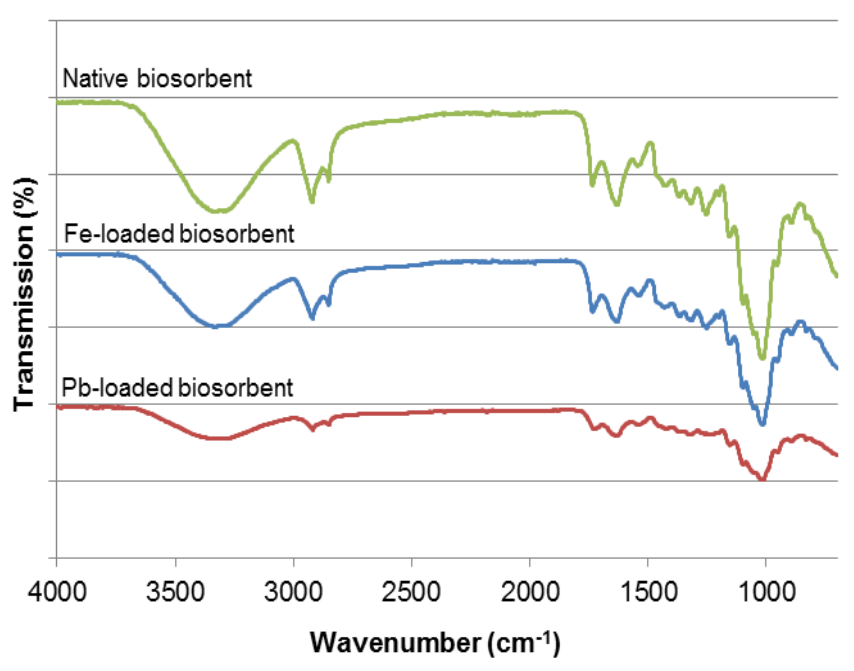

Fig. 9 FTIR spectra of native biosorbent, Fe- loaded biosorbent and Pbloaded biosorbent.

\section{CONCLUSION}

C. melo rind can be a promising low-cost adsorbent material for the removal of $\mathrm{Fe}$ and $\mathrm{Pb}$ ions from groundwater. The sorption study showed that $C$. melo rind successfully removes $\mathrm{Fe}$ and $\mathrm{Pb}$ ions in the groundwater samples up to $90.73 \%$ and $90.94 \%$, respectively, to a level below the WHO recommended limits of heavy metal for drinking water. The data were identified to fit to the Langmuir isotherm while kinetics study showed the biosorption of metal ions by C. melo rind follows the Pseudo-second order kinetics model. Based on the XRF analysis, it was identified that silica, $\mathrm{SiO}_{2}$ is the most abundant constituent in the biosorbent. The surface of the acidmodified biosorbent was observed to be more porous under the SEM. After the sorption process, new shiny particles were observed over the surface of the biosorbent. The FTIR spectra showed broad spectrum of hydroxyl and carboxyl groups in the native biosorbent and detected shifting of wavenumbers in metal-loaded biosorbent which suggested ion exchange or chemisorption mechanism may be involve in the biosorption process. From the findings discovered in this research, it is concluded that the $C$. melo rind has the potential to be further explored and developed as an inexpensive and eco-friendly biosorbent to remove metals in groundwater.

\section{ACKNOWLEDGEMENT}

This paper was fully sponsored by Fundamental Research Grant Scheme (FRGS Vot. 1575). The authors fully acknowledged Ministry of Higher Education (MOHE) and Universiti Tun Hussein Onn Malaysia for the approved fund which makes this important research viable and effective.

\section{REFERENCES}

Abdul Aziz, N, Othman, N. (2017). Soil characterization and groundwater quality. MATEC Web of Conferences, 103, 1-7.

A-Jacques, R., Lima, E. C., Dias, S. L. P., Mazzocato, A. C., Pavan, F. A. (2007). Yellow passion-fruit shell as biosorbent to remove $\mathrm{Cr}$ (III) and $\mathrm{Pb}$ (II) from aqueous solution. Separation and Purification Technology, 57(1), 193-198.

Azimah, N. M. A. (2012). Potential of using Rosa centifolia to remove iron and manganese in groundwater treatment (Master thesis). Universiti Tun Hussein Onn, Batu Pahat.

Azizul-Rahman, M. F. H., Mohd-Suhaimi, A. A., Othman, N. (2014). Biosorption of $\mathrm{Pb}$ (II) and $\mathrm{Zn}$ (II) in synthetic wastewater by watermelon rind (Citrullus lunatus). Applied Mechanics and Materials, 465-466, 906910.

Chatterjee, A., Schiewer, S. (2014). Effect of competing cations (Pb, Cd, Zn, and $\mathrm{Ca}$ ) in fixed-bed column biosorption and desorption from citrus peels. Water Air Soil Pollution, 225(1854), 1-13.

El-Araby, R., Hawash, S., El Diwani, G. (2009). Treatment of iron and manganese in simulated groundwater via ozone technology. Desalination, 249(3), 1345-1349.

Festus, A. A., Elvis, O. A., Morayo, A. B. (2013). Equilibrium sorption of lead and nickel from solutions by flame of the forest (Delonix regia) pods: Kinetics and isothermic study. Journal of Environmental Protectionl, 4(3), 261-269.

Gerola, G. P., Boas, N. V., Caetano, J., Tarley, C. R. T., Gonvalves Jr, A. C., Dragunski, D. C. (2013). Utilization of passion fruit skin by-product as lead (II) ion biosorbent. Water Air Soil Pollution, 224(1446), 1-11.

Hamilton, I. M., Gilmore, W. S., Strain, J. J. (2000). Marginal copper deficiency and atherosclerosis. Biological Trace Element Research, 78(13), 179-189.

Hashim, M. A., Mukhopadhyay, S., Sahu, J. N., Sengupta, B. (2011). Remediation technologies for heavy metal contaminated groundwater. Journal of Environmental Management, 92(10), 2355-2388.

Ho, Y. S. (2004). Pseudo-isotherms using a second order kinetics expression constant. Adsorption, 10(2), 151-158.

Igwe, J. C., Abia, A. A. (2007). Equilibrium sorption isotherm studies of Cd (II), $\mathrm{Pb}$ (II) and $\mathrm{Zn}$ (II) ions detoxification from wastewater using unmodified and EDTA-modified maize husk. Electronic Journal of Biotechnology, 10(4), 536-548.

Iqbal, M., Saeed, A., and Zafar, S. I. (2009). FTIR spectrophotometry, kinetics and adsorption isotherms modeling, ion exchange and EDX analysis for understanding the mechanism of $\mathrm{Cd}$ and $\mathrm{Pb}$ removal by mango peel waste. Journal of Hazardous Materials, 164(1), 161-171.

Kamaruudzaman, A. N., Tay, C. C., Ab Jalil, M. F., Abdul-Talib, S. (2013). Biosorption of iron (III) from aqueous solution using Pleurotus ostreatus spent mushroom compost as biosorbent. Advanced Materials Research, 781-784, 636-642.

Khamidun, M. H., Fulazzaky, M. A., Din, M. F. M., Yusoff, A. R. M. (2014). Resistance of mass transfer, kinetic and isotherm study of ammonium removal by using a Hybrid Plug-Flow Column Reactor (HPFCR). In W. P. Sun, J. C. M. Kao, and R. Chen (Eds.), Environment, Energy and Sustainable Development. Taylor \& Francis Group, London.

Langmuir, I. (1916). The constitution and fundamental properties of solids and liquids. American Chemistry Society, 38(11), 2221 - 2295.

MOH. (2010). National Guidelines for Raw Drinking Water Quality. Retrieved from http://kmam.moh.gov.my/public-user/drinking-water-quality-standar d.html

Mohamad Roslan, M. K., Mohd Kamil, Y., Wan Nor Azmin, S., Mat Yusoff, A. (2007). Creation of a groundwater quality index for an open municipal landfill area. Malaysian Journal of Mathematical Sciences, 1(2), 181-192.

Mohd-Asharuddin, S., Othman, N., Zin, N. S. M., Tajarudin, H. A. (2017). A chemical and morphological study of cassava peel: A potential waste as coagulant aid. MATEC Web of Conferences, 103, 1-8.

Mohd-Asharuddin, S., Othman, N., Zin, N. S. M., Tajarudin, H. A., Din, M. F. M. (2019). Flocculation and antibacterial performance of dual coagulant system of modified cassava peel starch and alum. Journal of Water Process Engineering, 31, 1-13. 
Noor-Syuhadah, S., Rohasliney, H. (2012). Rice husk as biosorbent: A Review. Health and the Environmental Journal, 3(1), 1-7.

Nurazim, I., Hamidi, A. A., Mohd Suffian, Y. (2015). Heavy metals concentration in river and pumping well water for riverbank filtration (RBF) system: case study in Sungai Kerian. Jurnal Teknologi, 74(11), 5967.

Othman, N., Mohd-Asharuddin, S. (2012). Local fruit waste as a potential biosorbent for wastewater containing heavy metals: An overview. IEEE Symposium on Business, Engineering and Industrial Applications, 352356.

Othman, N., Mohd-Asharuddin, S. (2013). Cucumis melo rind as biosorbent to remove $\mathrm{Fe}$ (II) and Mn (II) from synthetic groundwater solution. Advanced Materials Research, 795, 266-271.

Othman, N., Kueh, Y. S., Azizul-Rahman, F. H., Hamdan, R. (2014) Watermelon rind: A Potential Adsorbent for zinc removal. Applied Mechanics and Material, 680, 146-149.

Othman, N., Mohd-Asharuddin, S., Azizul-Rahman, M. F. H. (2013). An overview of fruit waste as sustainable adsorbent for heavy metal removal. Applied Mechanics and Materials, 389, 29-35.

Rao, K. S., Mohapatra, M., Anand, S., Venkateswarlu, P. (2010). Review on cadmium removal from aqueous solutions. International Journal of Engineering, Science and Technology, 2(7), 81-103.
Muhammad, R. M., Masdek, N. R. N. M. (2016). Overview of Melon Industry in Malaysia. FFTC Agricultural Policy Platform. Retrieved from http://ap.fftc.agnet.org/ap_db.php?id=677

APHA (1998). Standard method for the examination of water and wastewater $\left(20^{\text {th }}\right.$ ed.). Washington, DC: American Public Health Association, American Water Work Association and Water Environment Federation.

Valdman, E., Leite, S. G. F. (2000). Biosorption of $\mathrm{Cd}, \mathrm{Zn}$ and $\mathrm{Cu}$ by Sargassum sp. waste biomass. Bioprocess Engineering, 22(2), 171-173.

Volesky, B., Holan, Z. R. (1995). Biosorption of heavy metals. Biotechnology Progress Journal, 11(3), 235 - 250.

WHO (World Health Organization). 2004. Guidelines for drinking water quality recommendations. 3(1). Geneva: WHO.

Yesim, S., Yucel, A. (2000). Mass transfer and equilibrium studies for the sorption of chromium ions onto chitin. Process Biochemistry, 36(1-2), $157-173$.

Zayadi, N., Othman, N. (2013). Characterization and optimization of heavy metals biosorption by fishscales. Advanced Material Research, 795, 260265.

Zheng, H., Liu, D., Zheng, Y., Liang, S., Liu, Z. (2009). Sorption isotherm and kinetic modeling of aniline on Cr-bentonite. Journal of Hazardous Materials, 167(1-3),141-147. 